\title{
COPA DO MUNDO FIFA 2014 E OS IMPACTOS NA VIDA DA POPULAÇÃO DE BAIXA RENDA EM FORTALEZA-CE
}

\section{FIFA WORLD CUP AND IMPACTS IN THE LIFE OF LOW-INCOME POPULATION IN FORTALEZA-CE}

\author{
Larissa de Alcantara Viana ${ }^{1}$
}

\section{Resumo}

O presente trabalho tem como foco expor as ameaças de remoção e a luta da população pobre de frente às obras realizadas em função do megaevento Copa do Mundo FIFA 2014 na cidade de Fortaleza - CE. Para isso, faz uma recuperação histórica a partir da urbanização da cidade na década de 1930 e do processo de industrialização atrelado à política habitacional a partir da década de 1970, onde, neste período, analisa surgimento dos movimentos sociais urbanos e sua atuação frente à luta para conquistar moradia e bens de consumo coletivo. Posteriormente, com o anúncio da Copa do Mundo FIFA 2014, expõe as ações do Estado, a realidade das comunidades ameaçadas de remoção e o surgimento e a atuação de um novo movimento social que questiona as violações do direito à moradia digna em decorrência do megaevento. Para concluir, questiona a quem de fato serve esse modelo de cidade e quem usufrui do direito à cidade.

Palavras-chave: Copa do Mundo. Fortaleza. Moradia.

\section{Abstract}

This work focuses on exposing the threats of removal and the fight of the poor population in the face of the works carried out as a result of the 2014 FIFA World Cup mega event in the city of Fortaleza - CE. For it makes a historic recovery of the urbanization of the city in the 1930s and the industrialization process linked to housing policy from the 1970s, which, in this period, analyzes the emergence of urban social movements and their fight for housing and collective consumption goods. Later, with the announcement of the FIFA World Cup 2014 exposes the State's actions, the reality of threatened removal communities, in addition to the appearance and the performance of a new social movement that questions violations of the right to decent housing as a result of the mega event. Finally, the question for who actually serves this city model and who enjoys the right to the city.

Keywords: World Cup. Fortaleza. Dwelling.

\section{INTRODUÇÃO}

\footnotetext{
1 Mestranda no curso de Pós-Graduação em Arquitetura e Urbanismo da Faculdade de Arquitetura e Urbanismo da Universidade de São Paulo - FAU/USP. Bolsista CAPES. E-mail: larissa.aviana@gmail.com
} 
O presente trabalho busca compreender como ocorrem as ameaça e as remoções em função da Copa do Mundo FIFA 2014 na cidade de Fortaleza - CE. Essa população, historicamente excluída de direitos básicos, há anos luta pelo direito à cidade². Para isso faz-se necessário entender o histórico de urbanização da cidade, como acontecem as ameaças e as remoções da população de baixa renda em diferentes períodos e o modo de agir do poder público quando a população pobre encontra-se em locais de interesse público ou privado.

Desta forma o trabalho encontra-se estruturado em 3 momentos:

No primeiro busca-se compreender o desenvolvimento urbano da cidade, quando a população pobre começou a se instalar para além do traçado urbano da cidade. Posteriormente o processo de industrialização atrelado a políticas habitacionais, quando o Estado passou a atuar como produtor habitacional e a remover a população pobre para conjuntos habitacionais localizados nas periferias da cidade. Foi ainda nesse período que os movimentos sociais passaram a atuar questionando direitos básicos negligenciados pelo poder público.

No segundo momento procura compreender a realização da Copa do Mundo FIFA 2014 no Brasil onde o país tem como intuito adentrar a chamada globalização e como a realização do megaevento impactou na vida da população que sofreu ameaças e remoções em decorrência das obras para a realização do megaevento, especialmente a implantação do Veículo Leve sobre Trilhos (VLT). Nesse momento utiliza-se de entrevistas feitas pela autora com moradores de comunidades ameaçadas pelas obras. Os entrevistados têm sua identidade preservada.

Por fim, nas considerações finais, faz-se uma reflexão sobre a forma de atuação do poder público em relação às ameaças e às remoções nos diferentes períodos, buscando salientar quais são as características marcantes desses processos.

\section{URBANIZAÇÃO, CRESCIMENTO E POBREZA}

Historicamente a população de baixa renda concentra-se a oeste da cidade de Fortaleza. Essa aglomeração a oeste da cidade teve origem no início da década de 30 , quando houve uma

\footnotetext{
${ }^{2}$ Seguindo Harvey (2014), que recupera as ideias de Henry Lefebvre, o termo direito à cidade é utilizado como sendo: "muito mais do que um direito de acesso individual ou grupal aos recursos que a cidade incorpora: é um direito de mudar e reinventar a cidade mais de acordo com nossos mais profundos desejos. Além disso, é um direito mais coletivo do que individual, uma vez que reinventar a cidade depende inevitavelmente do exercício de um poder coletivo sobre o processo de urbanização. A liberdade de fazer e refazer a nós mesmos e a nossas cidades [...] é um dos nossos direitos humanos mais preciosos, ainda que um dos mais menos prezados. Qual seria, então, a melhor maneira de exercê-lo? [...] Reivindicar o direito à cidade [...] equivale a reivindicar algum tipo de poder configurado sobre o processo de urbanização, sobre o modo como nossas cidades são feitas e refeitas, e pressupõe fazê-lo de maneira radical e fundamental." (HARVEY, 2014, p. 28 - 30)
} 
enorme seca no estado e a população do interior, além de castigada pela seca, vítima também da consolidação do latifúndio e das precárias condições de trabalho, começou a migrar para a capital. O poder público, na tentativa de controlar o fluxo migratório, recebia os sertanejos na estação João Felipe que localiza-se no centro da cidade e os colocava no bairro Arraial Moura Brasil, adjacente ao Centro, sendo os dois bairros inclusive separados pela linha férrea. O Arraial Moura Brasil era cercado com varas e arame farpado e vigiado por soldados que controlavam os retirantes no local e os impediam de sair do perímetro permitido pelo poder público. Frente a essa receptividade na capital cearense, o Arraial Moura Brasil ficou conhecido como "campo de concentração" e também como "curral". Foi nesse período que Fortaleza começou a passar por um acentuado processo de crescimento demográfico que expande sua área urbana. Porém não houve ampliação suficiente de infraestrutura urbana, nem mesmo com o passar das décadas, o que gera graves consequências sofridas muitos anos depois. O crescimento industrial também não foi proporcional ao crescimento demográfico e a economia continuou estruturada na tradicional forma primário exportadora, uma vez que o processo de industrialização só ganhou maior efetividade a partir de meados da década de 1970.

\section{Industrialização, política habitacional, crescimento e pobreza}

No início da década de 1970, juntamente com a institucionalização das regiões metropolitanas brasileiras, no ano de 1973, foi criada a Região Metropolitana de Fortaleza (RMF), com intuito de compor o "conjunto de metrópoles criadas na década de 1970, a partir da iniciativa federal de consolidação de um eixo da geopolítica de integração e modernização do território nacional, com base na industrialização e em uma sociedade dominantemente urbana"³. Inicialmente compunham a RMF os municípios de Fortaleza, Caucaia, Maranguape, Pacatuba e Aquiraz. Posteriormente a RMF passou por alterações nas suas "composições políticoadministrativa alterada tanto pela fragmentação dos seus municípios originais, como pela inserção de novos municípios, alterações sempre legitimadas como estratégia espacial dos projetos de desenvolvimento econômico em curso" ${ }^{4}$. A composição atual da RMF pode ser observada na figura 01.

Figura 01: Atual RMF e ano de integração dos municípios

\footnotetext{
${ }^{3}$ DAVIDOVICH, apud RUFINO, 2012, p. 101.

${ }^{4}$ RUFINO, 2012, p. 101.
} 

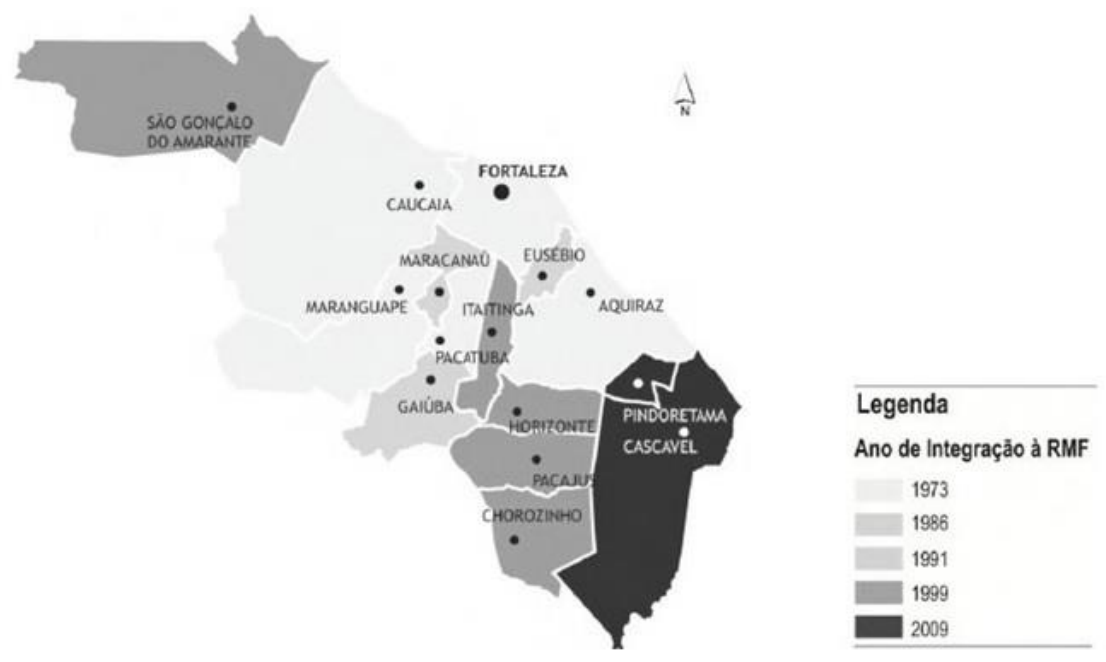

Fonte: Rufino (2012)

O planejamento da RMF agregava política habitacional com política de desenvolvimento industrial. Foi no município de Maracanaú que se implementou o primeiro distrito industrial do Ceará, em 1964. Pretendia-se ainda construir outro polo industrial no município de Caucaia, esse nunca concretizado. Porém, mesmo com o investimento industrial, especialmente com a criação do polo industrial da RMF, tendo havido inserção da classe trabalhadora no mercado de trabalho nas décadas de 60 e 70, essa se dava na forma de super exploração da mão de obra, sendo caracterizada pela baixa remuneração atrelada a exaustivas jornadas em precárias condições de trabalho.

A relação entre as longas jornadas de trabalho e os baixos salários pagos contribui para o desgaste físico e mental do trabalhador, tendo consequências sociais e psicológicas derivadas do grau de exploração. Caracterizam ainda esses trabalhadores explorados a espoliação urbana sofrida cotidianamente e caracterizada por suas habitações em condições precárias e desprovidas de infraestrutura básica como abastecimento de água, serviço de esgotamento sanitário, difícil acesso a transporte público, além de falta de acesso a serviços médicos e educacionais adequados, sendo esses elementos fundamentais para reprodução da força de trabalho. Kowarick (1979) define espoliação como o acúmulo de inexistência ou precariedade de elementos que transformam a cidade coletivamente, porém são usados individualmente, como o acesso à terra e à moradia, benfeitorias por parte de infraestrutura urbana, onde essas "apresentam-se como socialmente necessárias para a reprodução dos trabalhadores e aguçam ainda mais a dilapidação decorrente da 
exploração do trabalho ou, o que é pior, da falta desta" ${ }^{5}$. O autor ainda afirma que a espoliação urbana está diretamente ligada à exploração do trabalhador, porém não pode ser resumida a essa.

Vale ainda ressaltar que a política habitacional no Brasil tomou impulso ainda na década de 1960 com a criação do Banco Nacional de Habitação (BNH), quando "pela primeira vez começa a ser executada uma política de moradia que considerou a produção de habitação popular seguindo 'moldes empresariais'”. A lógica da produção em massa de moradias deu força à política habitacional regida pelo BNH, agente principal do Sistema Financeiro de Habitação (SFH) sendo este formado pelo Fundo de Garantia por Tempo de Serviço (FGTS) e pelo Sistema Brasileiro de Poupança e Empréstimo (SBPE), tendo funcionado fortemente como produtor de habitação ao invés de agente financeiro entre o ano 1964, quando foi criado, e 1986, ano de sua extinção.

Essa lógica de produção é retratada em diversas cidades de acordo com a maneira como foi produzida habitação de interesse social em forma de conjuntos habitacionais, localizados nas periferias, muitas vezes tornando-se verdadeiros bairros, impactando espacialmente e guiando o crescimento territorial das metrópoles.

Em Fortaleza, a construção desses conjuntos habitacionais, nas décadas de 1960, 1970 e 1980, regeu o crescimento territorial da cidade, que passou por processo de conurbação com os municípios de Caucaia e Maracanaú. Essa política de conjuntos habitacionais era retratada como forma de construção para a massa trabalhadora e a localização dos conjuntos estava diretamente ligada à produção industrial. Porém, de acordo com a figura 02, pode-se observar que embora o polo industrial localize-se no município de Maracanaú, foi na zona oeste da cidade, onde já havia grande concentração da classe proletária e de população miserável, que foram implantados dois dos três conjuntos habitacionais produzidos pelo BNH ainda na década de 1960.

\footnotetext{
${ }^{5}$ KOWARICK, 2000, p. 22.

${ }^{6}$ ARAGÃO, 2010, p. 82.
} 
Figura 02: Produção BNH década de 1960

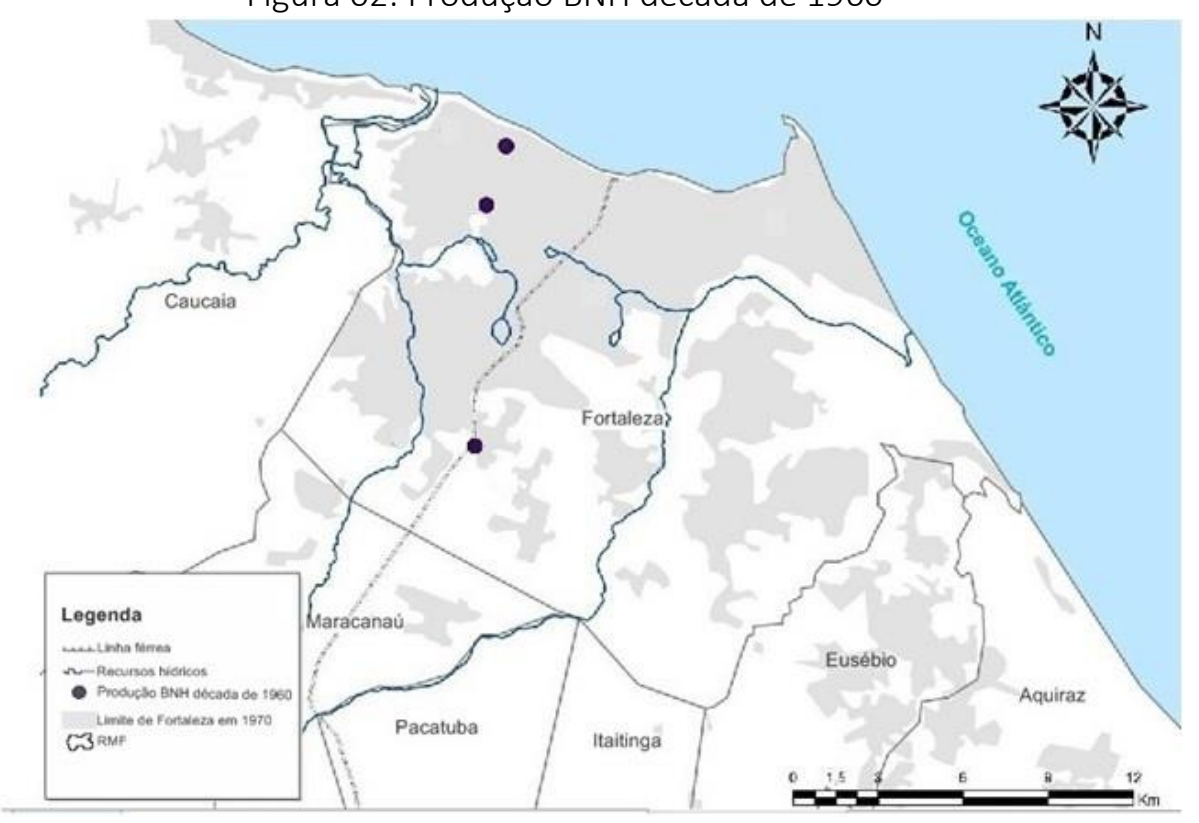

Fonte: Aragão (2010)

Embora tenha permanecido como principal órgão de desenvolvimento urbano durante toda a década de 1970, o BNH não conseguiu atingir a população pauperizada, que encontrava-se fora do mercado formal de trabalho e, dessa forma, não conseguiam arcar com as prestações do financiamento. Dessa maneira concentrou sua produção voltada parte à classe trabalhadora formal assalariada e outra parte à classe média.

Já em 1975, em nova produção de conjuntos habitacionais destinados à classe trabalhadora assalariada formal, repete-se o fator de localização distante das áreas centrais e providas de infraestrutura urbana e a localização passa novamente a ser nas franjas periféricas, desta vez nas fronteiras sul e sudeste da cidade, como pode ser observado na figura 03, onde encontravam-se maiores números de terrenos vazios com valor mais baixo. 
Figura 03: Produção BNH até década de 1970

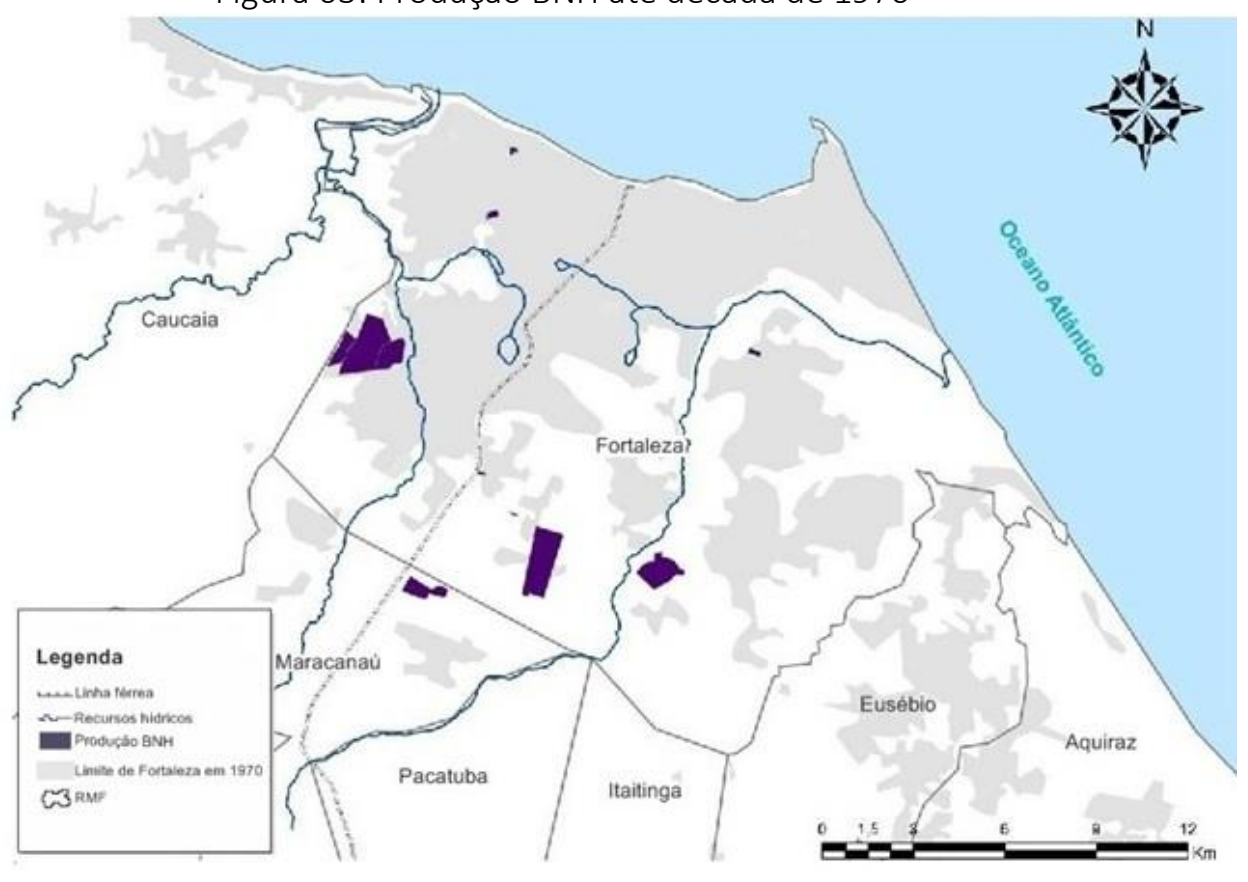

Fonte: Aragão (2010)

Com a implantação desses conjuntos nos extremos da cidade, o Estado, além de guiar territorialmente o crescimento da cidade e, com isso, causar uma verdadeira distinção socioespacial, deixando claro qual lado da cidade é destinada a qual classe social, ainda contribui para o processo de valorização fundiária, já que é necessário levar infraestrutura para esses conjuntos, passando estas por grandes vazios urbanos, em processo de especulação imobiliária, que serão beneficiados por esses investimentos.

\section{O coro dos excluídos}

Com a atuação da ditadura militar, a partir de 1964, houve nítida distinção entre Estado e Sociedade Civil. O Estado, militarizado e de postura autoritária, cerceou a opinião popular e a vida dos cidadãos que eram impedidos de manifestar qualquer tipo de descontentamento, anseio ou insatisfação. Com o "milagre econômico" durante a gestão Médici (1969 - 1974), caracterizada pela alta repressão, o Estado procurou compensar a insatisfação gerada nas camadas populares com a ilusão de melhoria do padrão de vida e de acesso a bens de consumo individuais. Porém, a tentativa de legitimar poder e povo não foi bem sucedida já que cada vez mais a ação do poder era excludente. 
Foi a partir da década de 1970, que vários grupos passaram a reivindicar seus direitos, se mobilizando em torno de questões como as salariais e de condições de trabalho. Nesse mesmo período acontecia em todo país protestos pela anistia política, que lutavam pelo fim da ditadura militar e pela abertura para um país democrático. Esse momento intensificou a união de vários segmentos sociais que trouxeram à tona duas importantes características da realidade brasileira: a pobreza urbana e o caráter excludente do Estado autoritário.

Frente à conjuntura nacional, Fortaleza, em menor escala, também se insere no processo de registrar e manifestar descontentamento e anseios. Porém, "a própria estrutura de poder do Ceará, onde velhas oligarquias controlam grande parte da economia do Estado, mantendo razoável poder de pressão na política estadual, impedem um avanço maior do movimento organizado das bases"7. Apesar do pequeno número de indústrias e da insegurança do trabalhador quanto à garantia do emprego, os movimentos sociais em Fortaleza surgiram, também, no interior das fábricas e nos sindicatos, bem como nas organizações de bairro contando com a forte atuação das Comunidades Eclesiais de Base (CEBs). Os movimentos pioneiros de bairro em Fortaleza antecederam os movimentos nacionais e surgiram ainda na década de 1960 no bairro Pirambú, que teve ação direta na luta pra conquistar o direito à terra e garantia de permanência no local, contando com forte apoio da Igreja Católica.

O Pirambú, um dos bairros mais populosos de Fortaleza, situado na orla marítima, a oeste da cidade, próximo ao centro e ao Arraial Moura Brasil, teve sua ocupação iniciada a partir da década de 1930 quando a população de trabalhadores informais e desempregada e a população miserável foi mantida fora do investimento habitacional estatal da época e teve como única opção ocupar áreas localizada à margem do traçado urbano existente, se caracterizou como o primeiro bairro a sofrer constantes ameaças de expulsão. No dia 1 de janeiro de 1962 os moradores, frente às cotidianas ameaças de remoções violentas, fizeram a "Marcha do Pirambú", reunindo 30 mil pessoas rumo ao centro, em luta pela terra. Apesar da tentativa de desocupação, o movimento, porém, teve causa vitoriosa. O Ministro da Viação decretou no dia 25 de maio a desapropriação da área para fins de interesse social. Foram destinados 98,6 hectares já ocupados por casas e barracos para que garantissem sua permanência, além de 52,5 hectares desocupados destinados para a urbanização do bairro ${ }^{8}$.

Outro movimento de forte impacto na cidade de Fortaleza foi o da favela José Bastos, já no ano de 1978. Trata-se da ocupação de terreno privado, localizado próximo à área central, na região

\footnotetext{
${ }^{7}$ BORZACHIELLO, 1992, p. 112.

${ }^{8}$ Fernandes, Diógenes e Lima, 1991.
} 
noroeste da cidade, que sofreu forte repressão policial quando o então proprietário do terreno entrou na justiça pedindo reintegração de posse. "O movimento da favela José Bastos foi reprimido com uma intensidade nunca vista - a polícia empregou armas de fogo, bombas de gás lacrimogênio e cães policiais" ${ }^{\prime \prime}$. Apesar de bastante repercussão, da expressão que o movimento ganhou em nível da cidade e de ter recebido apoio de vários segmentos da sociedade civil e de entidades como Instituto dos Arquitetos do Brasil (IAB) e Ordem dos Advogados do Brasil (OAB), o estado foi irredutível e não negociou. Deslocou a população para uma área desfavorável, distante do local onde residiam, trabalhavam, e do centro da cidade, com péssimas condições de transporte e de saneamento e, enquanto esperavam a construção das casas, tiveram que se alojar em barracos de lona. "A repressão policial contudo, é intensa, e os moradores acabam sendo transferidos para um terreno nas imediações do FRIFORT, próximo ao limite com o município de Caucaia, denominado Conjunto São Miguel”10.

Em Chagas Barreira (1991), uma das líderes do movimento avaliou, na época, que o conflito havia sido importante, pois foi a partir dele que descobriram novos aliados e avançaram na questão do problema de moradia, embora não tenham tido vitória nesse caso e, apesar de tudo, o estado ainda criou o PROAFA (Programa de Assistência às Favelas da Região Metropolitana de Fortaleza) que tinha como sua principal política deslocar a população para conjuntos habitacionais distantes da região central. Nesse período construiu três conjuntos em Fortaleza: Alvorada, Marechal Rondon e Palmeiras, localizados a doze, quatorze e dezoito quilômetros, respectivamente, do perímetro central da cidade, marcas de processos de segregação socioespaciais que se repetem.

Foi um marco dos programas e ações de desfavelamento a remoção da população de favelas em áreas centrais para conjuntos localizados nas franjas periféricas, em limites com cidades da RMF, distantes dos antigos locais de moradia e do centro da cidade, dificultando o acesso a empregos e serviços, levando o morador trabalhador a ter mais custo e gasto de tempo com transporte, produzindo assim a lógica habitacional de grandes conjuntos habitacionais, verdadeiros bairros, ocupando a periferia de Fortaleza. Esse processo aconteceu em nível nacional nas grandes cidades brasileiras, causando uma verdadeira higienização social e contribuindo para segregação social e territorial dos municípios.

Na figura 04 percebe-se espacialmente a localização das favelas no município de Fortaleza e o locais destinados como prioritários para as ações do desfavelamento, locais que abrigam os

\footnotetext{
${ }^{9}$ CHAGAS BARREIRA, 1991, p. 89.

${ }^{10}$ FERNANDES, DIÓGENES e LIMA, 1991, p. 63.
} 
grandes conjuntos habitacionais, o que nos leva a observar a remoção da população pobre sempre para as franjas periféricas.

Figura 04: Localização de favelas X área proposta pelo Plano de Desfavelamento, década de 1970
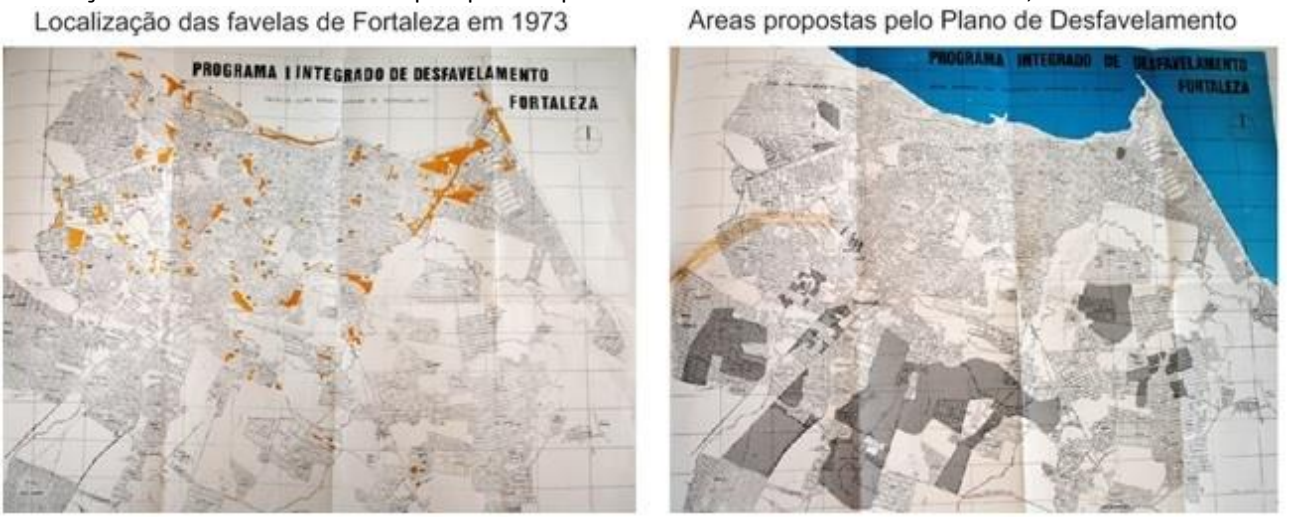

Fonte: Máximo e Lopes (2011)

Para além disso, ao tentar resolver o problema habitacional de parte da população com provisão de moradia, o Estado levou essas famílias a assumirem um financiamento de longo prazo que muitas não tiveram condições de arcar pois, além da prestação assumida por conta do imóvel, uma série de outros gastos geralmente não contabilizados anteriormente passam a existir a partir da aquisição da casa própria, como custos com energia elétrica, água, taxa de iluminação pública e de rede de esgoto, além do elevado gasto com transporte.

Como a maioria dos programas sociais concentrava-se nos governos estaduais e federais, é escassa a análise de programas relacionados ao governo municipal. Porém faz-se importante uma breve consideração sobre a gestão da prefeita Maria Luíza Fontenele (1986 - 1989). Maria Luiza foi a primeira mulher eleita prefeita da capital de um estado do país, além de primeira prefeita de capital eleita pelo Partido dos Trabalhadores (PT), logo no início da abertura democrática, rompendo com as antigas estruturas coronelista na administração municipal. Foi durante sua gestão, com intuito de colocar os movimentos sociais em espaço de contrapoder, na intenção de fazer pressão popular, que surgiu a proposta de Conselhos Populares.

O objetivo da criação de Conselhos Populares era que esse, articulado à prefeitura, porém independente, tivesse espaço nas decisões político administrativa do município e desenvolvessem programas de dimensões ampliadas, que fossem além da execução imediata e que, a partir daí, pudessem se contrapor à câmara dos vereadores e demais instâncias ligadas ao governo estadual. 
Vale ressaltar que as propostas dos Conselhos Populares não chegaram a ser implementadas nos bairros e nem integradas à prefeitura.

Sua administração fazia discurso de apoio e incentivo às organizações populares e com isso, respaldados na ideia de que não haveria repressão, surgiram greves, passeatas e as ocupações de terra tornaram-se mais intensivas. Frente a essa realidade, o governo municipal mantinha fortes divergências com o governo do estado, à época governado por Tasso Jereissati (PSDB), que não cedeu às pressões nem da prefeitura nem das comunidades. Assim, é possível observar a identificação dos movimentos populares com a gestão de Maria Luíza Fontenele que tinha, no seu programa governamental, o discurso governar o novo com o povo e que "em relação à intervenção na organização popular, a Prefeitura estabeleceu, dentre suas finalidades, 'apoiar as lutas por melhores condições de vida e de trabalho' e 'apoiar o movimento popular independente e autônomo'”11. Porém, apesar da tentativa de implantação, foi ineficaz a atuação dos Conselhos Populares.

Segundo Diógenes (1991), com essa "politização social", o Estado que, enquanto autoritário, apenas comunicava suas decisões à população, percebe a necessidade de construir uma articulação com os movimentos sociais, através de políticas sociais participativas. Aparentemente a ideia era romper com a linha de Estado contra movimentos sociais, bem como movimentos sociais contra Estado. Isso gera uma contradição para os movimentos sociais que nascem "contra" o Estado e "fora" dele, mas que necessitam dirigir-se a ele com frequência, no intuito de pressionar para conseguir conquistar condições básicas para a população. E pressionado para dar respostas a essas demandas o Estado precisa articular um canal de ligação direta com os movimentos sociais.

Dessa maneira os movimentos sociais passam por algumas alterações. Inicialmente tinham natureza mais reivindicativa, de ação direta, cobrando serviços e infraestrutura para os bairros, porém menos participativa. Nesse momento passam a reivindicar a participação da população organizada nas políticas públicas sociais e na construção coletiva de projetos e programas, no intuito de evitar o recebimento de projetos decididos a portas fechadas no interior dos gabinetes.

\section{PROTAGONISMO AMPARADO EM SEDIAR MEGAEVENTO}

Segundo Castells e Borja (1996), a luta das cidades por protagonismo teve início na Europa, durante a década de 1970, quando na tentativa de responder à recessão econômica da época, os governos locais foram além das obrigações em investimentos destinados a gerar emprego e renda

\footnotetext{
${ }^{11}$ FERNANDES e BARREIRA, 1991, p. 112.
} 
e fez coalizões com os principais atores econômicos e sociais urbanos na busca de promover as cidades. Os autores ainda afirmam que na América latina a tentativa das cidades em tomar protagonismo e tornar-se cidades globais aconteceu na década de 1990, quando as grandes cidades latino-americanas emergiram como atores políticos e econômicos, possibilitadas pela reestruturação da economia que permitiu visibilidade a partir da realização de projetos urbanos em grande escala, contribuindo, ainda, para a dinamização do setor da construção. Para que fosse consolidada a promoção das cidades latino-americanas, dependeria "da possibilidade de estímulo de grandes projetos de cidade que contem com uma participação ativa dos principais agentes públicos e privados e conquistem um amplo consenso público."12

Foi especialmente a partir da década de 1970 que os eventos esportivos passaram a compor o planejamento urbano, no intuito de trazer atrativos aos centros urbanos que caiam em desuso frente às novas centralidades urbanas.

De acordo com Vainer (2011), os megaeventos estão relacionados ao novo modelo de planejamento urbano, pautado no planejamento estratégico, onde os interesses do grande capital prevalecem ao da população. O autor ainda afirma ainda que os megaeventos fomentam a criminalização da pobreza: "se o objetivo é fazer da cidade uma vitrine, é preciso esconder tudo aquilo que gera críticas, tudo o que não se coloca na vitrine, que é pobreza, miséria. A cidade é reduzida a sua faceta de exportação, é voltada para exterior e não para os seus cidadãos."13

As cidades que se pretender protagonistas precisam competir entre si e, para isso, cada cidade individualmente precisa expor seus atrativos e carecem, necessariamente, dispor de serviços e equipamentos para conseguir atrair investimentos e eventos para si.

Em nome do 'povo' essas obras são projetadas, contratadas pelo Estado e executadas por empreiteiras particulares. Cabe saber, realmente, quem é o verdadeiro beneficiário destas obras, equipamentos ou serviços. Com a expansão da malha urbana e com o deficit acentuado da infraestrutura urbana e de equipamentos coletivos, além do 'insolúvel' deficit de habitação popular, o Estado tem se mostrado omisso na solução desses problemas." ${ }^{14}$

No dia 30 de outubro de 2007 o Brasil foi anunciado como país que receberia a Copa do Mundo FIFA 2014. Anterior a isso, 2006 foi o ano do crescimento econômico do país e 2007 foi também o ano de aumento significativo de renda do brasileiro, considerado pela Fundação Getúlio Vargas como o "ano da classe média". Com isso o país tinha o propósito de passar uma imagem de

\footnotetext{
12 CASTELLS e BORJA, 1996, p. 154 e 155.

13 VAINER, 2011, p. 01.

${ }^{14}$ BORZACHIELLO, 1992, p. 104.
} 
conquistas e desenvolvimento e conseguir garantir o padrão de país globalizado e, para isso, nada mais eficaz do que sediar um megaevento com forte repercussão no mundo inteiro.

\section{O furacão Copa do Mundo FIFA 2014}

Dentro do pacote das obras da Copa previstas para Fortaleza, o Veículo Leve sobre Trilhos (VLT), é a maior intervenção urbana, possui 12,7 km de extensão e atinge diretamente 22 bairros, causando transtorno a milhares de famílias. O número de famílias desapropriadas pelo projeto do VLT não é exato, ao longo do tempo teve bastante variação. De acordo com a imprensa local, em 2010 a estimativa era de $3.500^{15}$, em 2011 de $2.700^{16}$ e em 2013 era de 2.14017. De acordo com o Comitê Popular da Copa Fortaleza (CPC) a estimativa era de 10.000, 4.000 e 5.000 em 2011, 2012, 2013, respectivamente.

Além disso, sua implantação é bastante questionável devido ao alto valor de implementação (R\$ 273 milhões), do elevado custo de manutenção, da demanda existente para o percurso a que se destina, da sua real contribuição para a melhoria da mobilidade urbana e dos impactos socioespaciais causados por sua implantação. Vale ainda ressaltar que seu percurso passa preponderantemente por bairros nobres onde estes já contam com certos privilégios.

O Ramal Parangaba - Mucuripe está localizado sobre a área de maior renda "per capita" da cidade, permitindo o acesso entre as duas regiões com melhores índices nesse sentido, a II e a IV. Na região II está situada a maior parte dos edifícios altos da cidade, apresentando o modelo mais claro de ocupação vertical. Esses grandes edifícios correspondem, sobretudo com atividades comerciais e de serviços, com grande concentração de shoppings e apartamentos de alto nível, e com redes hoteleiras, de restaurantes e de equipamentos culturais. Por tanto, constitui o pólo da cidade que conta com as melhores condições de vida e de oportunidades geradoras de emprego e renda ${ }^{18}$.

Com o trajeto do VLT passando pelas Secretarias Executivas Regionais (SER) II e IV (figura 05), sendo estas as áreas mais nobres, com maior renda per capita e maior valorização imobiliária, torna-se perceptível a necessidade de remoção de pequenas áreas ditas indesejadas dentro dessa

15 Disponível em: http://diariodonordeste.verdesmares.com.br/cadernos/cidade/obra-do-metrofor-na-viaexpressa-gera-polemica-1.688420. Acesso março de 2013.

16 Disponível em: http://diariodonordeste.verdesmares.com.br/cadernos/negocios/aprovado-rima-do-vltfamilias-questionam-1.712813. Acesso em março de 2013.

$17 \quad$ Disponível

em:

http://www.opovo.com.br/app/opovo/brasil/2013/01/07/noticiasjornalbrasil,2983700/atrasos-nas-

remocoes-afetam-o-ramal-do-vlt-em-fortaleza.shtml. Acesso em março de 2013.

${ }^{18}$ CEARÁ, 2011, p. 22. 
grande área de valorização. Essa é a região da cidade com maior investimento por parte do poder público e é também nessa área onde localiza-se o coração financeiro e imobiliário da cidade.

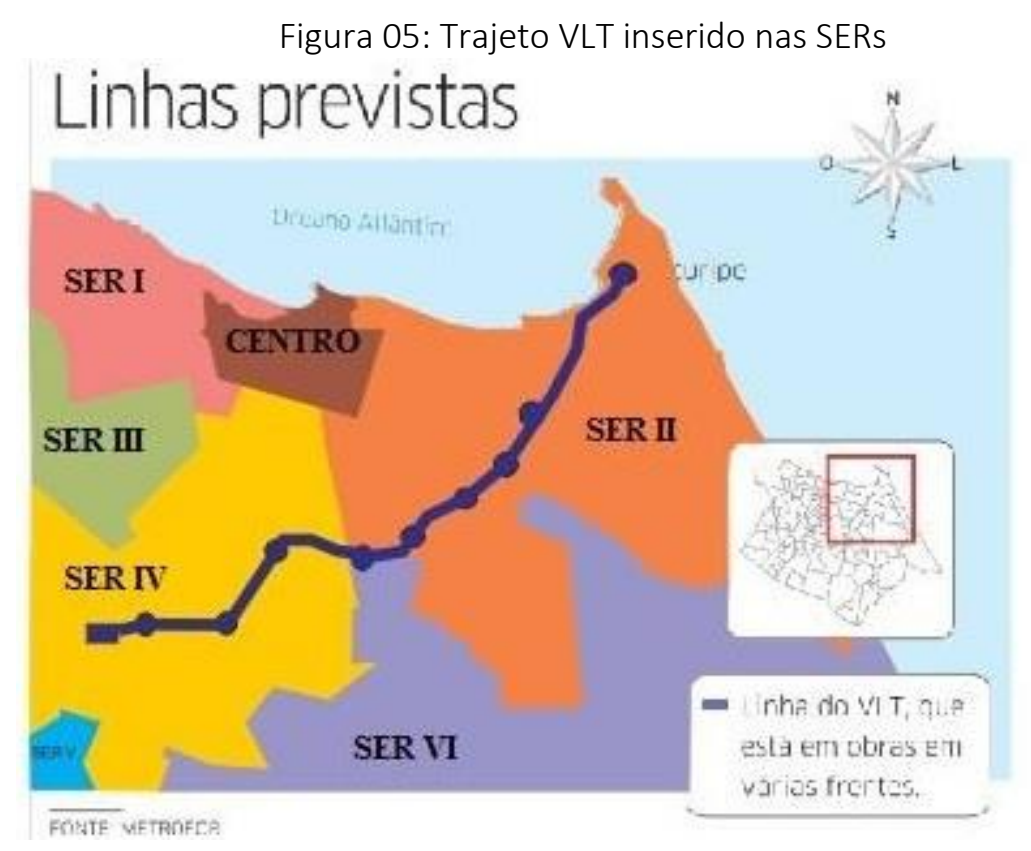

Fonte: Disponível no site do Governo do Estado do Ceará, acesso outubro de 2014

Fortaleza é uma cidade com graves problemas de mobilidade urbana. Isso se dá por conta da largura estreita das vias, falta de conectividade entre as avenidas, alto índice de transporte individual o que gera constantes congestionamentos. Soma-se a isso o pouco investimento em transporte público, sendo este de péssima qualidade, sem horário fixo, além da precariedade dos passeios e da pouca arborização em uma cidade de verão durante o ano inteiro, tornando-a nada atrativa à utilização das ruas e do transporte público.

Perante isso o governo do estado viu a necessidade de implementar modal que não causasse maiores transtornos aos turistas durante a Copa do Mundo FIFA 2014. Para o governo do estado, a localização do VLT Parangaba/Mucuripe, junto ao eixo Via Expressa/Raul Barbosa, tem como meta fazer a ligação entre a zona hoteleira (Avenida Beira Mar, orla de Fortaleza localizada no bairro Meireles), o Porto do Mucuripe, que com o novo Terminal de Passageiros passará a 
receber turistas que ficarão no local atracados em navios e iates, o estádio Castelão (atualmente Arena Castelão), centro da cidade e aeroporto. Ou seja, a princípio tratava-se de uma megaobra com objetivo de locomover o turista no período de Copa do Mundo. Apesar da proposta de ligação entre essas áreas, vale manifestar que a ligação entre a zona hoteleira/Porto do Mucuripe à Arena Castelão só será possível se integrada a linhas de ônibus e para a ligação entre a zona hoteleira/Porto do Mucuripe e o Centro é necessária a integração do VLT à Linha Sul do METROFOR. Além disso, esse trajeto é completamente desnecessário, uma vez que a zona hoteleira/Porto do Mucuripe localiza-se a leste da cidade, ao lado do Centro e a Parangaba fica situada a sudoeste, então quem pega o VLT no Cais do Porto teria que ir até a Parangaba para fazer a integração com a Linha Sul do METROFOR e, só então, se deslocar para o Centro. A distância entre os bairros pode ser melhor observada na figura 06.

Figura 06: Espacialização Cais do Porto, Castelão, Centro, Parangaba

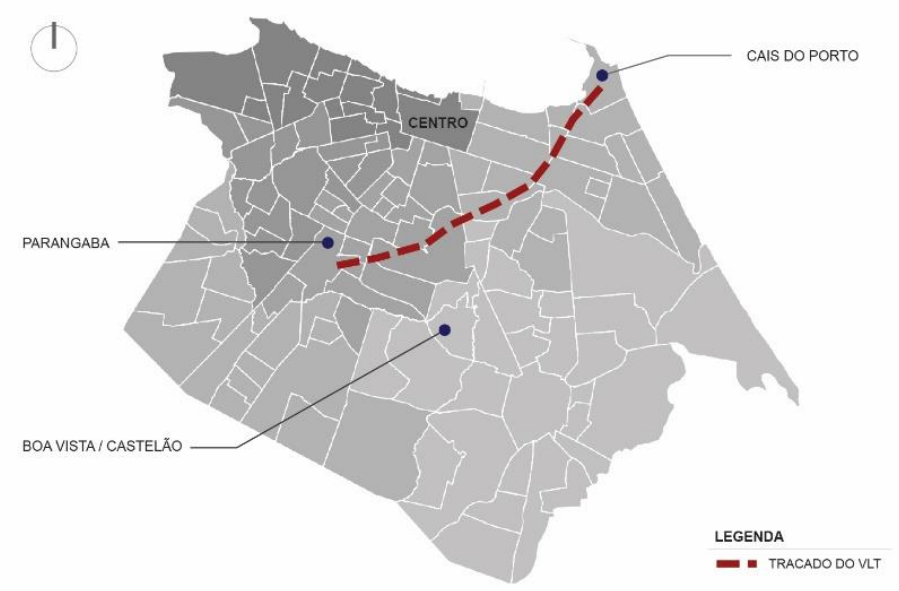

Fonte: Elaboração própria (2015)

\section{O Comitê Popular da Copa}

Para lutar por questões relacionadas à Copa, foi formado, em 2010, o Comitê Popular da Copa Fortaleza (CPC). O CPC trata-se de uma organização local de movimentos sociais, ONG's, organizações populares, organizações políticas e da sociedade civil que luta pela garantia dos direitos humanos no processo da Copa das Confederações 2013 e Copa do Mundo FIFA 2014. Age estudando, denunciando e lutando contra os impactos nas comunidades atingidas e que mantém resistência em áreas que estão sendo modificadas pelas obras da Copa, além de pautas concretas e inegociáveis sobre a violação de outros direitos de trabalhadores e da sociedade civil. 
Foi no intuito de reverter as consequências tanto no espaço físico quanto no que se refere às violações dos direitos humanos que surgiram os Comitês Populares da Copa, nas doze cidades sede, na forma de articulação de movimentos sociais, para lutar na tentativa de minimizar as violações cometidas em função do megaevento e, para além da tentativa de alterar esse quadro, também denunciar violações dos direitos humanos cometidas em função do megaevento, além de questionar e promover dados encobertos pelo governo.

O CPC Fortaleza resistiu às fortes pressões e lutou para conseguir o direito da população permanecer nas casas que há anos habita, locais de valor sentimental e também de investimento financeiro por parte da população ali residente. Vale ressaltar que o CPC logrou várias vitórias no processo de luta e resistência relacionado às remoções, conseguindo diminuir o número da população removida e reverter o valor das indenizações. É preciso ainda manifestar que apesar da Copa já ter acabado, as ameaças de remoção continuam, especialmente as relacionadas à obra do VLT, que não ficou pronto a tempo e, atualmente, encontra-se parada.

\section{Comunidades atingidas pelo megaevento}

As comunidades Lauro Vieira Chaves e João XXIII são duas das comunidades atingidas pelas megaobra do VLT. A autora fez visitas às comunidades, bem como entrevistou moradores, que têm suas identidades preservadas. Através das visitas e das entrevistas, observou-se as características descritas a seguir.

A comunidade Lauro Vieira Chaves, localizada próxima aos bairros Vila União e Montese (figura 07), dois bairros de centralidade própria na capital cearense, foi formada, em terreno ocioso, no início da década de 1960 por pessoas vindas do interior do estado e também da própria capital. De acordo com o governo do estado a terra pertence à União e, ao seu lado, encontra-se o Aeroporto Internacional de Fortaleza que tem sua área delimitada por um muro com arame farpado, como pode ser observado na figura 08.

Figura 07: Localização da comunidade Lauro Vieira Chaves e seu entorno 


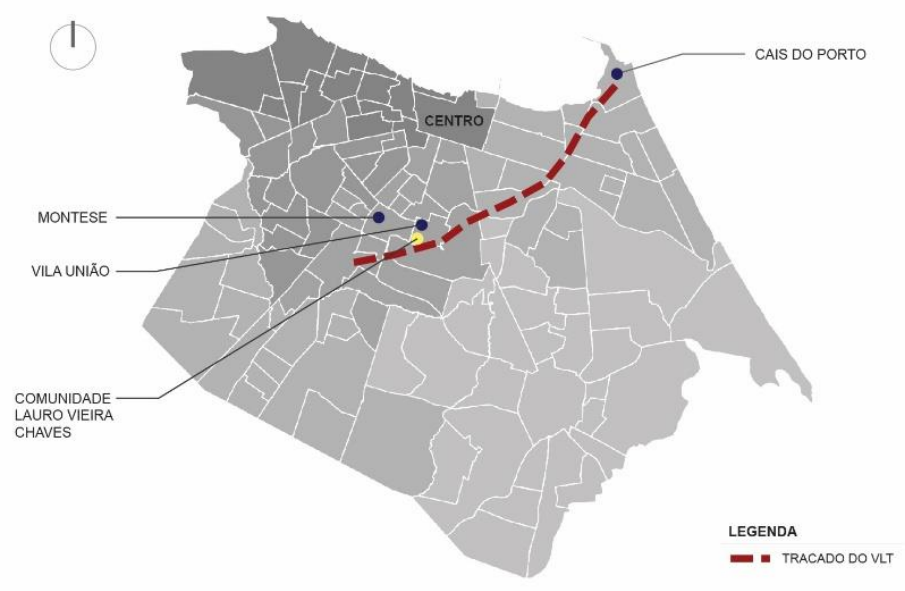

Fonte: Elaboração própria (2015)

Figura 08: Detalhe da relação comunidade Lauro Vieira Chaves, linha férrea e cerca do aeroporto

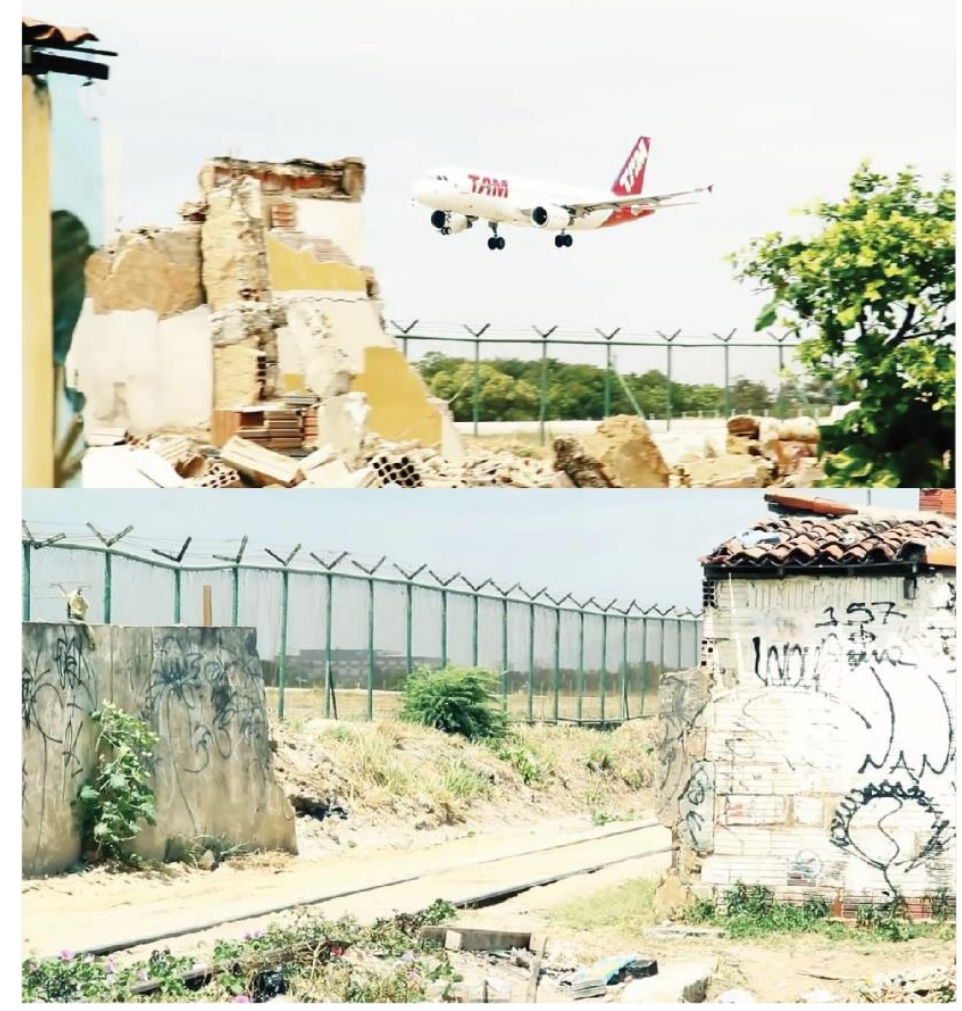


Fonte: vídeo \#CopaParaQuem? A comunidade que desviou o trem. Publicado em 11 de fevereiro de 2014. Disponível em https://www.youtube.com/watch?v=7hi4G0jPpIA, acesso outubro de 2014, tratada pela autora (2015)

Os moradores lutam há 30 anos por saneamento básico em toda sua extensão, que atualmente é parcial. Toda comunidade é provida por abastecimento de água, coleta de lixo. A drenagem de águas pluviais é superficial, energia elétrica geral com medidor, a iluminação pública oficial é precária, vias de acesso para veículos em toda comunidade, parte das vias pavimentadas de asfalto e outra parte de areia. Quanto ao padrão construtivo das casas da comunidade, prevalece alvenaria com revestimento, a predominância do gabarito é horizontal de até 2 pavimentos. A comunidade desenvolve um projeto de cineclube que surgiu a partir de uma oficina dada no local por um coletivo de audiovisual e, a partir de então, a comunidade passou a fazer o cineclube quinzenal para os moradores e frequentadores da região.

Na comunidade existia um centro comunitário, porém este foi desativado e a prefeitura alegou que seria construído um Centro Urbano de Cultura, Ciência, Arte e Esporte (CUCA). No centro comunitário havia piscina onde a população praticava natação e hidroginástica, contava ainda com aulas de ballet e ligado ao equipamento havia um posto de saúde, atualmente o único equipamento mantido pela prefeitura. Após a destruição do equipamento público o espaço se transformou em uma garagem destinada a carros da Guarda Municipal. Depois de muito questionamento da comunidade a garagem foi desativada e a prefeitura passou a afirmar que a área estava destinada à construção de moradia para parte da comunidade que seria removida por conta da obra do VLT Parangaba/Mucuripe. Até a presente data nada foi feito neste terreno.

Não há dados exatos quanto ao número de famílias na comunidade mas, pela consolidação do local, estima-se que em cada casa resida apenas uma família. A renda mensal é de média de 1 a 2 salários mínimos. É totalmente consolidada, com vínculos fortes inclusive entre vizinhança e não há índice de violência.

De acordo com o entrevistado, a comunidade compõe o CPC desde seu início, em 2010, quando passou a ser ameaçada de remoção por conta da obra do VLT, batizado pelos moradores de VLTS: Veículo Levando Teus Sonhos. A prefeitura fez medição, entrou nas casas, tirou fotos e marcou sem explicar qual a função. Na marcação eram colocado números e letras na parede MT03AouB (Metrô Trecho 03, casa Acima ou Baixo). A partir de então a comunidade se fechou para pesquisas ou qualquer chegada de funcionários do governo. Frente a isso o governo se propôs a iniciar um tímido diálogo com a população que passou a resolver tudo por consenso. E por consenso resolveram dialogar com o governo que mostrou a proposta dizendo quem sairia ou não. 
Houve nova reunião para saber se aceitariam a empresa ir fazer o cadastro de quem sairia e foi consenso que sim. Um mês depois moradores foram intimados a comparecer a um auditório público, de forma separada, mostrando a nítida tentativa de desarticular o movimento, parte no período da manhã e parte no da tarde, lá foram informados sobre as remoções por conta do VLT com valor de indenização muito abaixo do mercado, entre 4 e 16 mil reais. Houve gente idosa que passou mal quando soube da notícia. Na mesma noite fizeram uma grande convocação e reunião para decidir como agiriam, e foi tirada uma comissão de representação perante os órgãos públicos. A comunidade fez um vídeo, junto ao CPC, denunciando as violações cometidas e em uma intervenção fizeram adesivos com a sigla MT: Meu Território e coloram em cima da marcação do governo.

No projeto inicial estavam previstas a remoção de toda a comunidade, 203 casas, aproximadamente 1.200 pessoas. Com os questionamentos e denúncias da comunidade junto com o CPC, o número de remoção caiu uma média de $70 \%$ e foi para 66 casas. Nessa luta questionaram o traçado do VLT, onde o traçado inicial saia do traçado original já existente da linha férrea e passava por cima da comunidade fazendo uma curva, então os moradores perceberam que essa curva era desnecessária e lutaram em função de mudar o traçado. Medidas de exigência para provar que havia espaço foram feitas pelo poder público e respondida pelos moradores. Foi através disso que mudou a quantidade de casas removidas e que 13 dessas 66 casas encontram-se em áreas remanescentes, havendo a possibilidade de reaver parte de suas moradias locais.

A proposta por parte do governo para os removidos era pagamento relacionando apenas a edificação. $\mathrm{O}$ valor mais alto era de $\mathrm{R} \$ 16$ mil e o mais baixo de $\mathrm{R} \$ 2$ mil. As primeiras indenizações pagas a moradores que se sentiram coibidos a deixar suas casas variaram de $R \$ 4.000,00$ a $R \$$ $16.000,00$, e isso aguçou ainda mais a união da população no intuito de lutar e resistir. Na própria comunidade há o caso de seu Zé Maria que ficou muito conhecido por ter sua casa avaliada frente ao valor de mercado por $\mathrm{R} \$ 185.000,00$ e pela avaliação do governo do estado por $\mathrm{R} \$ 16.000,00$. Através das reivindicações em audiências públicas, assembléias e Ministério Público, a comunidade tinha 3 objetivos: a não remoção de toda a comunidade; o remanejamento das famílias removidas para uma área próxima; e a garantia através da Lei 15.194 de 19 de julho de 2012, onde proprietários de imóveis residenciais ou mistos, que residissem no mesmo, de valor até $R \$ 40$ mil, considerando o terreno e as benfeitorias, devidamente regularizados, receberiam a indenização correspondente e mais uma unidade do programam habitacional do governo federal Minha Casa, Minha Vida (MCMV) viabilizada e custeada pelo Estado e os proprietários de imóveis residenciais ou mistos, devidamente regularizados, que residissem no mesmo, de valor acima de $\mathrm{R} \$ 40$ mil, 
considerando o terreno e as benfeitorias, receberiam a indenização correspondente e uma unidade residencial viabilizada pelo poder público, mas cabendo ao beneficiário o custeio das prestações. Aos definidos como posseiros, residentes por no mínimo doze meses ininterruptos, anterior a data da publicação da Lei e que tenham imóveis avaliados no valor de até $\mathrm{R} \$ \mathbf{4 0}$ mil, considerando apenas benfeitorias, receberiam a indenização correspondente e mais uma unidade MCMV viabilizada e custeada pelo Estado. E aos definidos como posseiros, residentes por no mínimo doze meses ininterruptos, anterior a data da publicação da Lei e que tenham imóveis avaliados no valor superior a $\mathrm{R} \$ 40 \mathrm{mil}$, considerando apenas benfeitorias, receberiam a indenização correspondente e mais uma unidade MCMV viabilizada pelo Estado, mas cabendo ao beneficiário o custeio das prestações. Inquilinos e ocupantes, residentes por no mínimo doze meses ininterruptos, anterior a data da publicação da Lei, seriam cadastrados para receber uma unidade habitacional do MCMV viabilizada pelo Estado, mas cabendo ao beneficiário o custeio das prestações. Para todas essas possibilidades, o local seria definido pela Secretaria de Infraestrutura. Questionavam também que o lugar do reassentamento, que inicialmente seria no bairro José Walter localizado no extremo sul da cidade (figura 09), distante $14 \mathrm{~km}$, fosse mudado para terreno dentro da comunidade, a 3 quadras da comunidade, pertencente à prefeitura, inativo há 10 anos, sendo cadastrado como praça, porém é apenas um terreno baldio murado.

Figura 09: Localização da Comunidade X área destinada à realocação

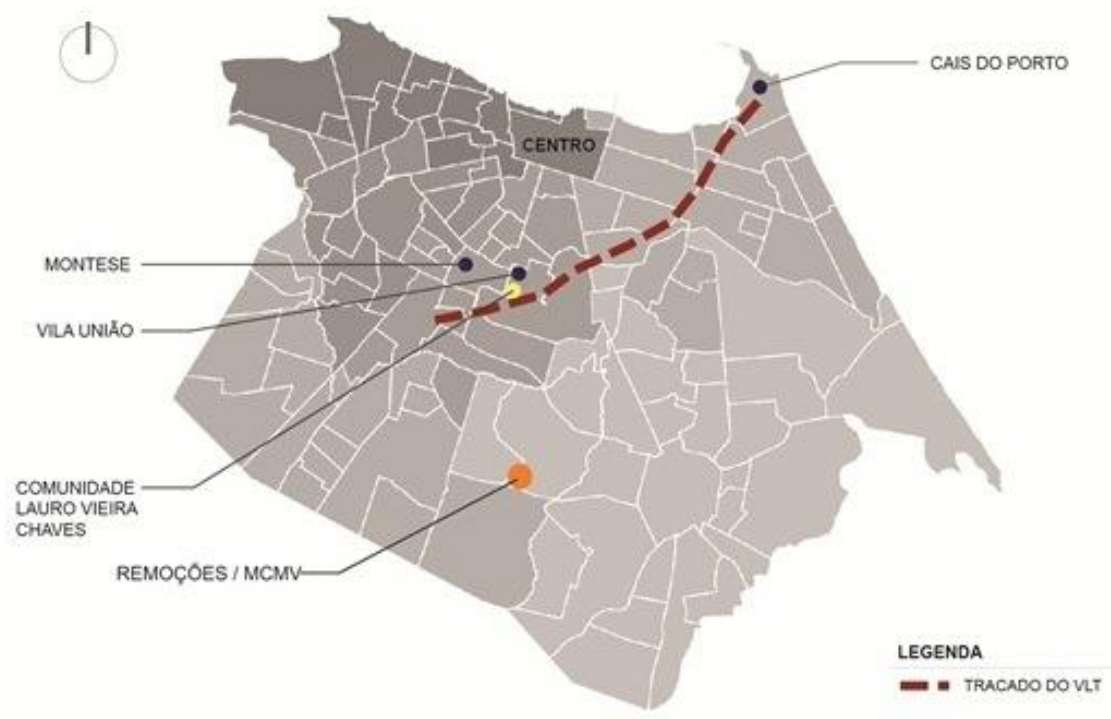

Fonte: Elaboração própria (2015) 
Os moradores da Lauro Vieira Chaves até a presente data seguem na luta por justa indenização ou realocação próxima à atual comunidade, visto que as obras do VLT ainda não foram concluídas e atualmente encontram-se paradas e as ameaças de remoção continuam, mesmo após a realização da Copa do Mundo FIFA 2014.

A comunidade João XXIII (figura 10) trata-se de uma ocupação em terra da União, que teve início em meados da década de 1940 e encontra-se às margens da linha férrea, onde existem diversas comunidades, no bairro Dionísio Torres, bairro este bastante central, completamente inserido na malha urbana, onde predominam moradores de renda média e alta. Ao longo da linha férrea existem várias comunidades, uma delas é a João XXIII e tem ainda Jangadeiro, Trilha do Senhor, Dom Oscar Romero, Aldaci Barbosa, todas elas compõe a comunidade do Trilho. Na figura 11 é possível observar algumas comunidades localizadas às margens do trilho.

Figura 10: Localização Comunidade João XXIII

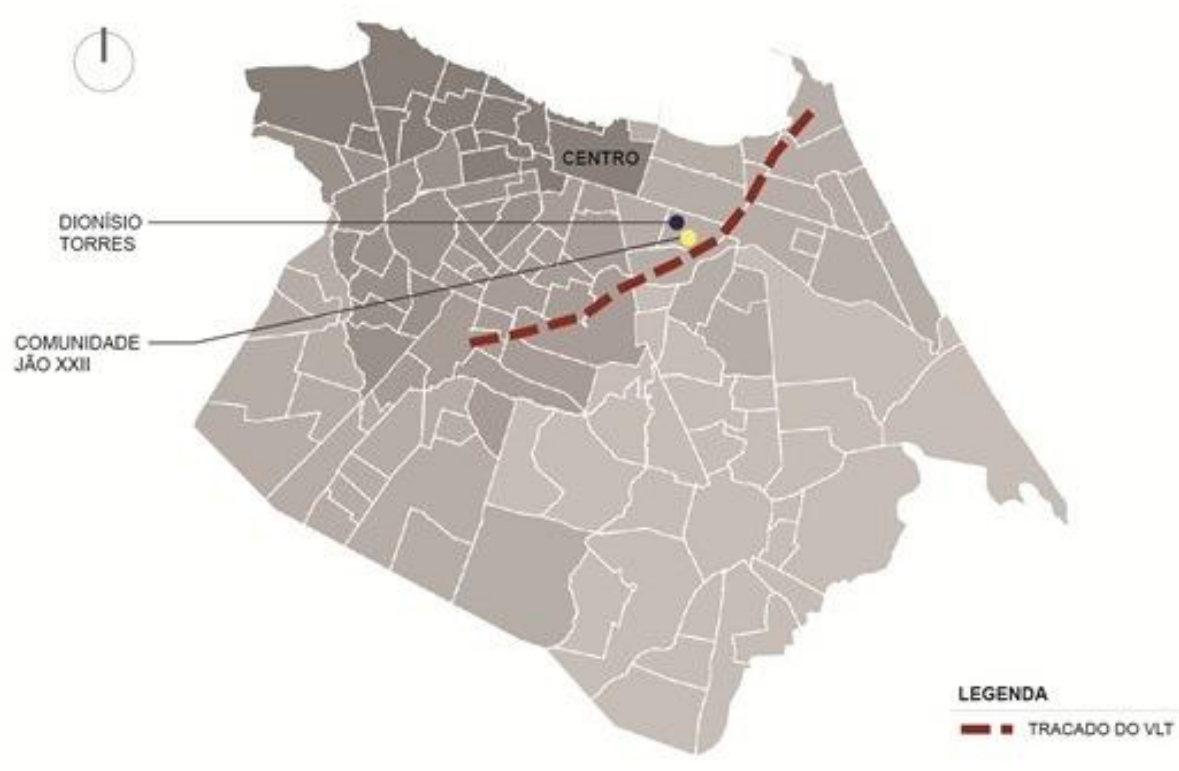




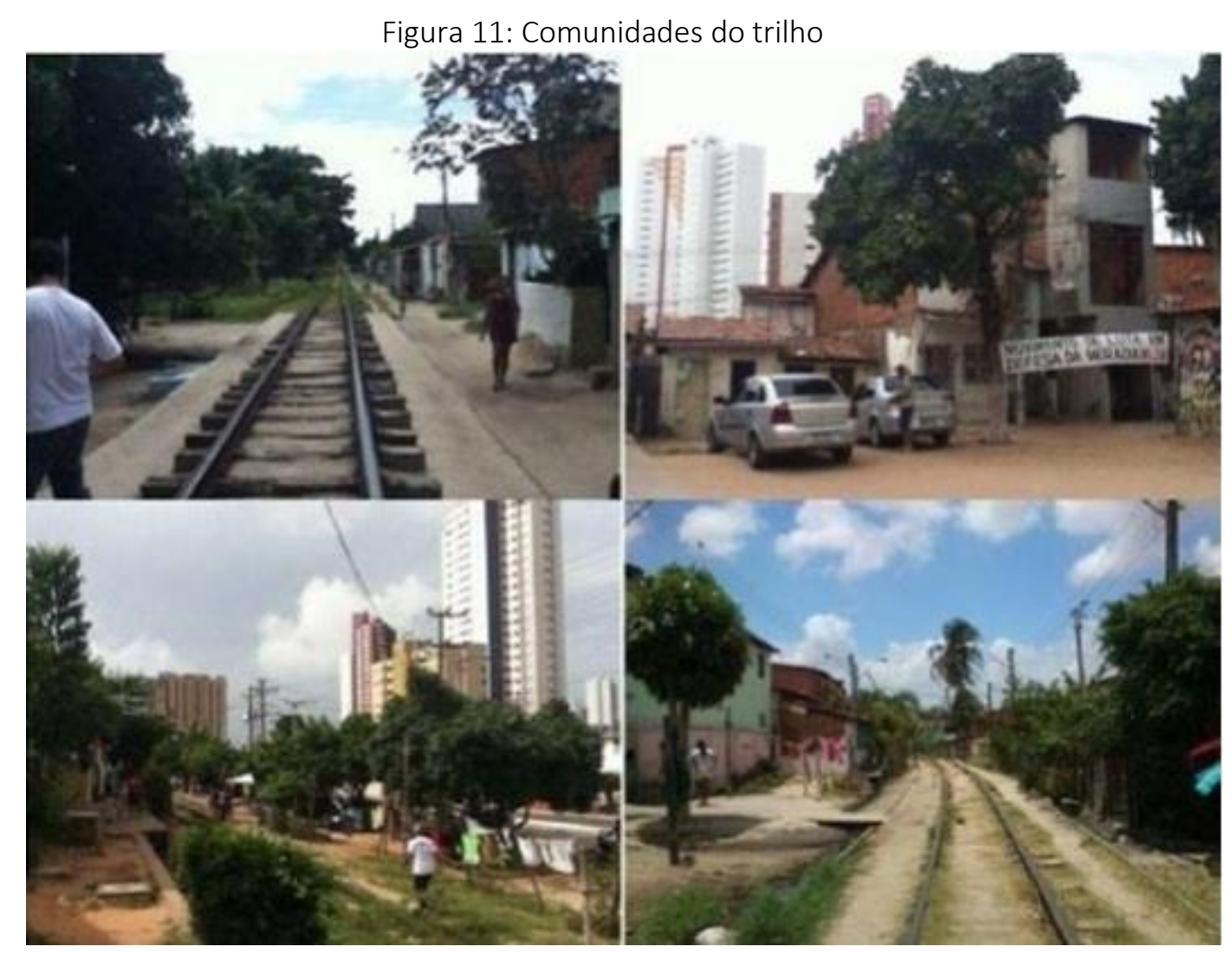

Fonte: lacovini (2013)

Porém, de acordo com a entrevistada, a família Jorge Vieira alega ser dona do terreno e possui várias casas na localidade que aluga para outras famílias. No início da comunidade muitos moradores compraram o terreno desta família. Não existe nenhum tipo de processo jurídico. Alguns moradores têm o documento de compra e venda, apesar de muitos já terem comprado de terceiros. Estima-se que 1.200 famílias vivam na comunidade e que a renda mensal varie entre 0 e 1 salário mínimo. O poder público caracteriza o local como favela, porém os moradores não se reconhecem como tal, mas sim como comunidade que já é bastante consolidada e onde não há registros de violência.

Através de muita reivindicação e abaixo assinados conseguiram implementar rede total de abastecimento de água e parcial de esgotamento sanitário. Entretanto, a comunidade ainda possui certa carência como drenagem de águas pluviais, mas não há risco ambiental. Existe um container na adjacência onde é necessário levar o lixo para que o caminhão da prefeitura recolha. Alguns moradores ainda possuem ligação de energia clandestina, especialmente das casas que ficam à margem do trilho, pois não há postes. Foi feito também abaixo assinado solicitando a 
implementação de postes, mas não foram atendidos. Existe ligação pública de energia, mas esta é precária. Na comunidade há apenas uma via de acesso a carro e, com exceção desta, as demais vias não são pavimentadas.

Apesar de existência de algumas carências, a comunidade é bastante consolidada e inserida na malha urbana. Há pontos de ônibus que servem à localidade, sendo a quantidade de transporte público considerada excelente, além de ter acesso a taxi e mototaxi. Na comunidade vizinha, bem próxima, existe escola e posto de saúde. A própria comunidade é bem servida de pequenos comércios e existe muita oferta de serviços nos arredores. De forma organizada e coletiva, os próprios moradores construíram uma capela dentro da comunidade e esta é usada também como centro comunitário, acontecendo nela as reuniões de moradores. O padrão construtivo predominante é de alvenaria com revestimento e o gabarito é horizontal.

A Comunidade João XXIII está ameaçada de remoção por conta das obras do VLT. Para implementação do mesmo o governo do estado alega que além de fazer uso da linha férrea já existente seria necessário a implementação de mais duas linhas férreas. Ao todo são 22 comunidades ao longo do trilho atingidas pelo projeto do VLT que lutam há quatro anos na tentativa de reverter a quantidade de remoção em função da implementação. Na comunidade João XXIII mais de 10 famílias que residiam à margem da linha férrea já foram removidas e uma média de outras 10 famílias estão ameaçadas de remoção direta e indiretamente. Parte destas famílias estão ameaçadas pelo próprio governo, outra parte pelo proprietário das casas que alugam. Porém, ambos os casos é por conta das obras do VLT.

Os moradores foram surpreendidos por funcionários do governo do estado que chegaram à comunidade para medir, fotografar e marcar as casas sem dar informações sobre o que estava acontecendo. Quando o governo se dispôs a conversar, inicialmente afirmou que os moradores precisavam deixar suas casas e que seriam indenizados com base no valor do imóvel, sem incluir o valor da terra, uma vez que se tratava de posseiros.

Outras comunidades ao longo do trilho estavam passando pelo mesmo processo de ameaça e então se uniram ao CPC para reivindicar não apenas as ameaças de remoção mas, no caso das remoções acontecendo, como seriam as indenizações. Ocorre que as primeiras indenizações variaram entre $R \$ 4.000,00$ e $R \$ 16.000,00$. Isso serviu ainda mais de incentivo para a união relacionada à luta e resistência. A partir de então, com a articulação e a luta, conseguiram reverter a forma de indenização que, teoricamente, passou a ser com base na Lei 15.194 de 19 de julho de 2012. Porém, o local destinado aos removidos, continua a fortalecer a luta, pois trata-se dos conjuntos habitacionais construídos pelo MCMV no bairro do José Walter, super distante do 
atual local de morada onde aquelas pessoas já fincaram seus laços e têm relação com o local e seu entorno (figura 12).

Figura 12: Localização da Comunidade X área destinada à remoção

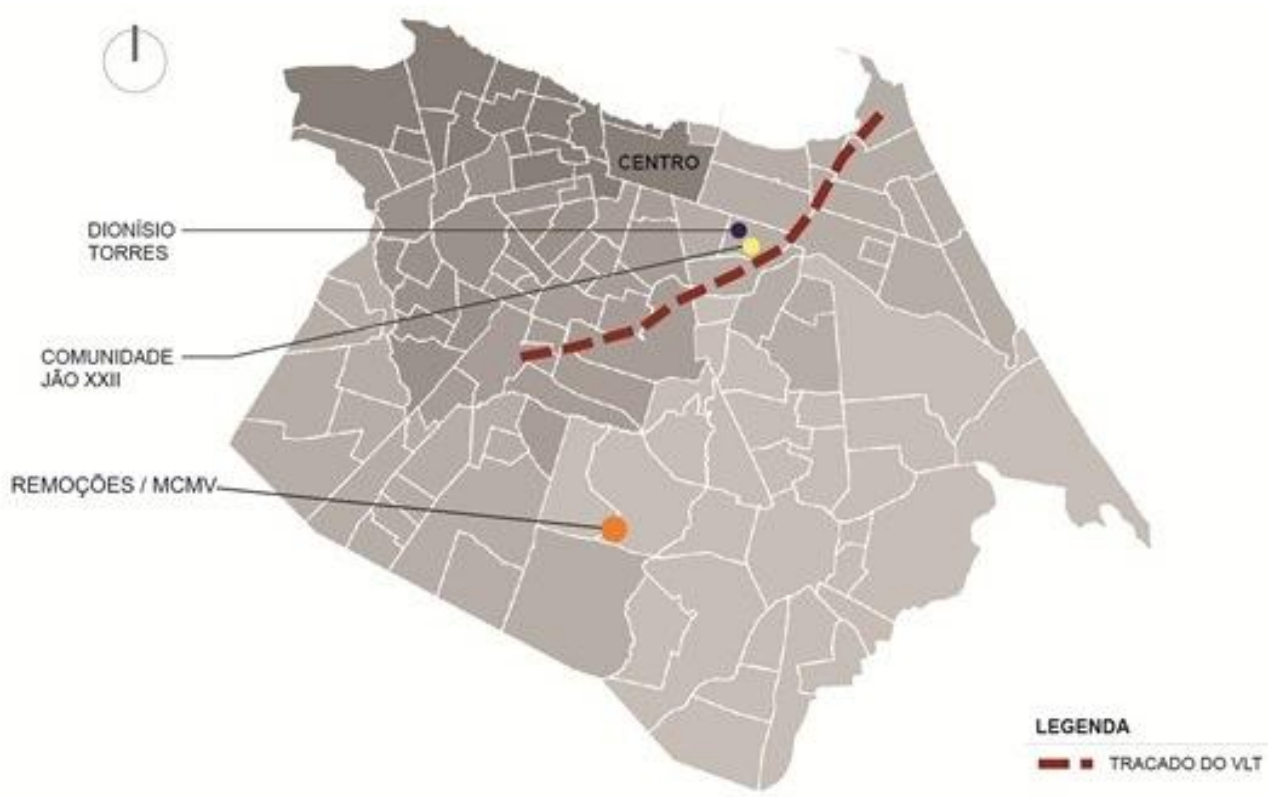

Fonte: Elaboração própria (2015)

Outra conquista foi a mudança no valor da bolsa aluguel, que trata-se de um auxílio do governo do estado para os moradores removidos conseguirem alugar um local até que as unidades habitacionais destinadas para eles sejam finalizadas. Inicialmente o governo havia anunciado o valor de R\$200,00, com a luta junto ao CPC conseguiram reverter o valor para $\mathrm{R} \$ 400,00$. Há uma contradição quanto ao período da bolsa aluguel. Há quem diga que seria por um ano e quem afirme que seria até a entrega da casa, porém era afirmado pelo governo que a construção dos novos empreendimentos do MCMV seriam entregues em um ano, logo o tempo seria o mesmo. Sua luta atual é para que o conjunto do MCMV destinado a eles seja na Cidade 2000, pois é bem mais próximo da atual localidade, como pode ser melhor observado na figura 13.

Figura 13: Localização Comunidade João XXIII X Cidade 2000 X área destinada à remoção 


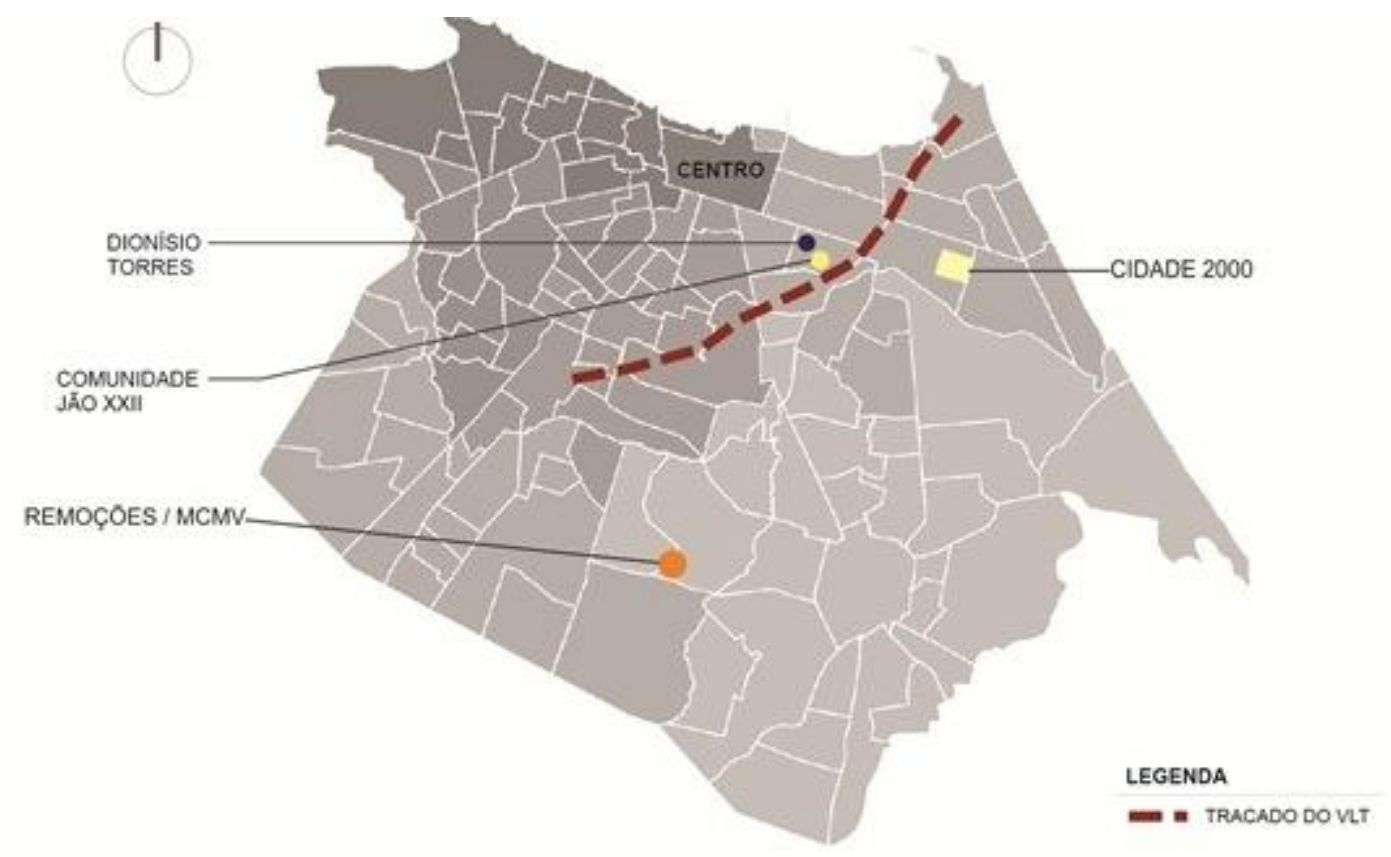

Fonte: Elaboração própria (2015)

Os moradores da comunidade João XXIII comemoram também como vitória o atraso da obra do VLT, que não foi entregue para a Copa do Mundo FIFA 2014 e encontra-se temporariamente parada e, com isso, ganharam tempo e maior força na luta e resistência.

\section{Fortaleza e a copa das remoções}

Considerando a Comunidade Lauro Vieira Chaves e a Comunidade João XXIII, sendo as duas diretamente atingidas por obras em função da Copa do Mundo FIFA 2014, é possível observar que as comunidades já estão consolidadas, ou seja, o processo de conquista da moradia já foi encerrado. O que acontece atualmente é o processo de resistência para conseguir manter-se na localidade. Apesar de grande parte dos moradores não possuir segurança da posse do ponto de vista jurídico legal, a comunidade já é consolidada e grande parte da população vive no local há pelo menos 40 anos. A área já foi fruto de intervenções para melhoria da infraestrutura, contando com água encanada, iluminação domiciliar e pública, acesso a meios de transporte, integração à malha urbana. O que aconteceu a partir do momento em que Fortaleza se tornou uma das cidades sede da Copa do Mundo 2014 foi que os investimentos para melhoria da infraestrutura e imobiliários para a viabilização do mundial geraram um medo crescente relativo à possibilidade de remoção, possibilidade essa muitas vezes concretizada. Com isso, consolidou-se um movimento de resistência, uma luta para garantir o que já havia sido conquistado anos atrás: a busca pela 
permanência. Em ambos os casos é possível observar que inicialmente a proposta do governo era de indenização pautada apenas no valor do imóvel, pois alegava que os moradores eram posseiros e haviam invadido as terras. Durante todo o processo de luta e resistência, as duas comunidades conseguiram reverter esse processo de indenização e conseguiram agregar uma parte do valor aplicado ao solo, bem como receber unidade habitacional do MCMV. Porém, o local destinado para o reassentamento encontra-se no extremo sul da cidade, distante dos locais onde os moradores da comunidade residem há anos, trabalham, estudam e ficaram laços. Nota-se a repetição na lógica de reassentamento distante do local de moradia, consequentemente longe do local de trabalho e do ambiente onde a população fincou laços. Percebe-se ainda que os locais destinados aos removidos são carentes de infraestrutura, quando muitos desses moradores estão inseridos em áreas dotadas de infraestrutura, o que mostra que localidades consolidadas não estão destinadas à população pobre da cidade.

Além disso, a adoção dessa postura no que se refere à remoção e reassentamento distante da área onde as famílias moram e sem a consulta e participação destas, agride o Plano Diretor Participativo de Fortaleza que afirma:

Art. 5o [...] - garantia de alternativas habitacionais para a população removida das áreas de risco ou decorrentes de programa de recuperação e preservação ambiental e intervenções urbanísticas, com a participação das famílias nas tomadas de decisões e reassentamento prioritário em locais próximos às áreas de origem do assentamento ${ }^{19}$;

Junto a isso é possível observar o interesse por parte do poder público e a grande força da iniciativa privada em fazer uma verdadeira higienização social nas áreas de valorização e especulação, deixando nítido qual o local destinado a cada classe social na cidade, como mostra Borzachiello (1992):

Uso e localização do solo urbano estão intimamente vinculados às classes sociais que os detém, daí o fato de certos serviços e equipamento, como também de determinadas infra-estruturas estarem vinculadas, quanto à sua presença e funcionamento, aos detentores daqueles. Esta situação é tão evidente que ao analisar a distribuição dos serviços urbanos sob a responsabilidade do Estado no espaço da cidade, Singer identifica de imediato que estes só atendem aos moradores de rendimentos elevados ou médios. ${ }^{20}$

É essa lógica de reassentar os moradores distante da região da comunidade onde viveram a vida inteira e de limpeza social, que destina à população de baixa renda sempre locais periféricos e distantes da área central, o questionamento a quem de fato serve essa cidade, que tem dando

\footnotetext{
${ }^{19}$ FORTALEZA, 2009, p. 02.

20 BORZACHIELLO, 1992, p. 95.
} 
continuidade ao movimento de luta e resistência dos moradores que desejam continuar próximos à sua localidade de origem e que resistem e desejam fazer parte da cidade que ainda é para poucos.

\section{CONSIDERAÇÕES FINAIS: O SEU CHÃO É SAGRADO}

Observa-se a repetição da forma de agir por parte do poder público quando o assunto é remover a população pobre residente em áreas centrais e ares de interesse de expansão e imobiliário.

Com o intuito de adentrar a chamadas cidades globais, Fortaleza já possuía uma série de projetos que foram intensificado e justificados pela realização da Copa do Mundo FIFA 2014. Notase que esses projetos encontram-se em áreas centrais, providas de infraestrutura, áreas de expansão e de grande interesse do capital imobiliário, tornando estas áreas atrativas para investimentos e não permeáveis pela população de baixa renda que constantemente sofre com a implantação desses projetos, sendo removidas para lugares distantes.

Desde o início do desenvolvimento urbano da cidade de Fortaleza, na década de 30 e, posteriormente do processo de industrialização na década de 70 , já ficou claro que local era destinado ao pobre na cidade. Mesmo quando o Estado atua de forma a prover habitação para a população pobre, essa habitação vem em forma de unidade habitacional desprovida de infraestrutura e distante da centralidade, o que contradiz o direito à cidade, como mostra Pereira (1986): "já não se pode tratar de simplesmente proporcionar uma casinha ao operário, mas de suprir também as carências mais amplas que resultam do próprio desenvolvimento da cidade enquanto lugar de moradia que, cada vez mais, está indissociável do espaço urbanizado."21

Observa-se que as constantes obras em função do "progresso" sempre rebatem na vida da população de baixa renda que constantemente é removida para locais mais distantes da centralidade, uma população que vive sempre às margens e que quando a infraestrutura chega nunca consegue usufruir porque é retirada de forma autoritária da sua localidade.

A cidade "transformada em coisa a ser vendida e comprada, [...] não é apenas uma mercadoria mas também, e sobretudo, uma mercadoria de luxo, destinada a um grupo de elite de potenciais compradores: capital internacional, visitantes e usuários solváveis." 22 Frente a isso, observa-se que o direito à habitação, não apenas enquanto um teto e quatro paredes, mas sim

\footnotetext{
21 PEREIRA, 1986, p. 218.

22 VAINER, 2000, p. 83.
} 
indissociável do acesso a infraestrutura, serviços, lazer, o que configura o direito à cidade, é apenas para poucos, apenas para a população que pode pagar por algo que deveria ser um direito, porém, que exclui, historicamente, os moradores pobres da cidade cada vez mais mercadoria.

\section{REFERÊNCIAS BIBLIOGRÁFICAS}

ARAGÃO, Thêmis. Influência das políticas habitacionais na construção do espaço urbano metropolitano de Fortaleza. Dissertação de Mestrado. Rio de Janeiro: Instituto em Planejamento Urbano e Regional (IPPUR)/ Universidade Federal do Rio de Janeiro (UFRJ), 2010.

BORZACHIELLO, José. Quando os incomodados não se retiram: uma análise dos movimentos sociais em Fortaleza. Fortaleza: Multigraf Editora, 1992.

CASTELLS, Manuel e BORJA, Jordi. As cidades como atores políticos. Novos Estudos CEBRAP, n. 45, p. 152 - 166. 1996.

CEARÁ, Governo do Estado. Estudo de Impacto Ambiental - Relatório de Impacto Ambiental Projeto do Veículo Leve sobre Trilhos - VLT - Fortaleza/CE. Tomos A, B e C. Fortaleza: Superintendência Estadual do Meio Ambiente, 2011.

CHAGAS BARREIRA, Maria Socorro. A Intervenção Planejada e o Discurso da Participação. In: E. BRAGA e I. BARREIRA (Org.). A política da Escassez: Lutas Urbanas e Programas Sociais Governamentais (77-109). Fortaleza: Fundação Demócrito Rocha, 1991.

FERNANDES, Adelita e BARREIRA, Irlys. A Gestão do "Popular" na Experiência de Poder Municipal. In: E. BRAGA e I. BARREIRA (Org.). A política da Escassez: Lutas Urbanas e Programas Sociais Governamentais (111 - 123). Fortaleza: Fundação Demócrito Rocha, 1991.

FERNANDES, Adelita; DIÓGENES, Glória e LIMA, Maria Cláudia. Movimentos Sociais Urbanos em Fortaleza: trajetória de um novo sujeito social. In: E. BRAGA e I. BARREIRA (Org.). A política da Escassez: Lutas Urbanas e Programas Sociais Governamentais (39 - 75). Fortaleza: Fundação Demócrito Rocha, 1991.

FORTALEZA 2009. Lei № 062 de 02 de fevereiro de 2009. Institui o Plano Diretor Participativo do Município de Fortaleza e dá outras providências. [Online]. Fortaleza: Diário Oficial de Câmara Municipal de Fortaleza. Disponível: http://www.fortaleza.ce.gov.br/sites/default/files/pdp_com_alteracoes.pdf. [Acesso 03 de julho de 2013].

KOWARICK, Lúcio. A Espoliação Urbana. Rio de Janeiro: Paz e Terra, 1979.

Escritos Urbanos. São Paulo: Ed. 34, 2000.

PEREIRA, Paulo César Xavier. Valorização imobiliária, Movimentos Sociais e Espoliação. In: Sinopses (USP), São Paulo, v. 9, 1986. p. $203-233$.

RUFINO, Beatriz. Incorporação da metrópole: centralização do capital no imobiliário e nova produção do espaço em Fortaleza. Tese de Doutorado. São Paulo: Faculdade de Arquitetura e Urbanismo (FAU) / Universidade de São Paulo (USP), 2012. 
VAINER, Carlos. Pátria, empresa e mercadoria. In: ARANTES, O.; VAINER, C. e MARICATO, E. (ORG). A cidade do pensamento único: desmanchando consensos. Rio de Janeiro: Petrópolis, 2000. p. 75 105. \begin{tabular}{cccc} 
Entrevista & Carlos & Vainer. & Disponível \\
\hline$<\mathrm{http}: / /$ carosamigos.terra.com.br/index2/index.php/noticias/1344entrevistacarlosvaine?format $=\mathrm{p}$
\end{tabular} df $>$. Acesso em: 17 de maio de 2011.

Trabalho enviado em 11 de fevereiro de 2015.

Aceito em 31 de março de 2015. 